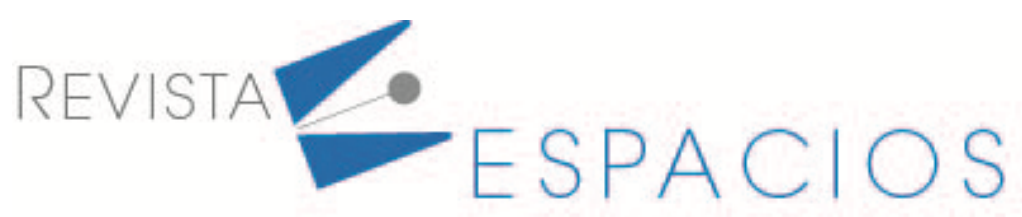

\title{
Basic abilities a good university teacher should have: case study at the University of Lleida, Spain
}

\author{
Habilidades básicas que debe tener un buen profesor universitario: el caso de la Universidad \\ de Lleida, España
}

REVERTER-MASIA, Joaquin ${ }^{1}$
HERNANDEZ-GONZALEZ, Vicenç $^{2}$

\begin{abstract}
In this article we evaluated the opinion of university students regarding the competences a good professor should have. The information was obtained from a survey distributed through digital devices to a total of 1.433 students from the University of Lleida, Spain. The two most important competences were to clearly explain the contents followed by motivational stimulation. The least valued were stimulation for participation and collaborative work, and coordination with professors. The highest evaluation was directed to communicative, interpersonal relationship, and methodological competences.

key words: higher-education; university teacher competences; higher educational quality; surveys; university students; spain

Resumen

En este artículo se evaluó la opinión de los estudiantes universitarios sobre las competencias que un buen profesor debería tener. Información obtenida mediante una encuesta distribuida a través de dispositivos digitales a un total de 1.433 estudiantes de la Universidad de Lérida, España. Las dos competencias más importantes fueron explicar claramente los contenidos seguida por la estimulación de la motivación. Las menos valoradas fueron la estimulación para la participación y el trabajo colaborativo, y la coordinación con los profesores. La evaluación más alta se dirigió a las competencias comunicativas, las de relación interpersonal y las metodológicas.

Palabras clave: enseñanza superior; competencias del profesorado universitario; calidad de la educación superior; encuestas; estudiantes universitarios; españa
\end{abstract}

\section{Introduction}

The establishment of the European Higher Education Area (EHEA), social changes, and their application to the university have brought change in the role of university professors (Rodríguez-Gómez \& Gairín, 2015). Teaching competences in Higher Education are grounds for extensive debates and studies (Zabalza, 2003; Valcárcel, 2005; Tejada, 2009; Mas \& Tejada, 2013).

\footnotetext{
${ }^{1}$ Full Professor. Didactics Specifics Department. University of Lleida (Spain). Joaquim.reverter@udl.cat

2 Tenure-Track Lecturer. Didactics Specifics Department. University of Lleida (Spain).Vicenc.hernandez@udl.cat
} 
The functions of university teaching staff go beyond the classroom, where the didactic act takes place. The design and planning of such training, the evaluation of acquired and/or developed competences and professional contributions to the improvement of the developed training action and their participation in the academicorganizational dynamics of their institution must be considered (Mas \& Tejada, 2013).

The main teaching competences of the university professor were identified in a joint project between an Interuniversity Group of Teacher Training (IGTT, Studies and Analysis, EA 2010-0099), constituted by Catalan public universities' units and training centers (Torra-Bitlloch et al., 2012; Triadó, Estebanell, Márquez, \& Del Corral, 2014). Transversal competences considered most relevant for this role by teaching staff were obtained from analysis: interpersonal, methodological, communicative, planning and teaching management, teamwork, and teacher innovation (Torra-Bitlloch et al., 2012; Triadó et al., 2014).

Definition of identified competences:

- Interpersonal competence (IC): To promote a critical spirit, motivation and confidence, recognizing cultural diversity and individual needs while creating a climate of empathy and ethical commitment.

- Methodological competence (MC): To apply methodological strategies (learning and evaluation) appropriate to students' needs, in order to be consistent with the objectives and evaluation processes, as well as to incorporate information technology and communication to improve teaching-learning processes.

- Communicative competence (CC): To develop bi-directional communication processes in an effective and appropriate manner, including message reception, interpretation, production and transmission through different channels and media, contextualized to the teaching-learning situation.

- Teaching planning and management competence (TPMC): To design, guide and develop contents, training and evaluation activities, and other resources linked to teaching and learning, so that results are valued and improvement proposals are elaborated.

- Teamwork competence (TWC): To collaborate and participate as a group member, assuming responsibility and commitment to tasks and functions assigned to achieve common objectives, following agreed procedures and attending to available resources.

- Innovation competence ( $\mathrm{InnC}$ ): To create and apply new knowledge, perspectives, methodologies and resources in the different dimensions of teaching activity, aimed at improving the quality of the teachinglearning process.

This research was completed through another project (REDU2012), where teaching staff sample was amplified to include the rest of Spanish universities, as well as include students' opinion, in order to validate competencies and indicators (Table 1). 
Table 1

Equivalence between student survey items and teaching competencies

\begin{tabular}{|l|c|}
\hline \multicolumn{1}{|c|}{ Items (Student survey) } & $\begin{array}{c}\text { Equivalent } \\
\text { Competence }\end{array}$ \\
\hline 1. Stimulate reflection, criticism and self-criticism & IC \\
\hline 2. Promote a trusting and tolerant environment in the classroom & IC \\
\hline 3. Motivate students in their learning process & IC \\
\hline 4. Use teaching-learning methods consistent with subject objectives & MC \\
\hline 5. Use assessment procedures consistent with subject objectives & MC \\
\hline 6. Encourage participation and collaborative work & MC \\
\hline $\begin{array}{l}\text { 7. Provide feedback on the learning process and encourage its } \\
\text { reorientation }\end{array}$ & CC \\
\hline 8. Clearly explain the contents & CC \\
\hline 9. Listen to students (promote dialogue) & TPMC \\
\hline 10. Inform about the planning of the subject & TPMC \\
\hline 11. Highlight the most relevant contents in the course and profession & TPMC \\
\hline 12. Clearly specify criteria and evaluation systems & TPMC \\
\hline 13. Fulfill the program/guide the course & TWC \\
\hline 14. Coordinate with other teachers of the same course & TWC \\
\hline 15. Coordinate with faculty on different courses & InnC \\
\hline 16. Propose innovations that improve the teaching-learning process & MC: \\
\hline $\begin{array}{l}\text { IC: interpersonal competence; MC: methodological competence; CC: } \\
\text { TPMC: teaching planning and management competence; TWC: Teamwork competence; InnC: } \\
\text { innovation competence. }\end{array}$ & \\
\hline
\end{tabular}

One of the objectives proposed in this project was to collect and analyze students' opinion on teaching quality in terms of favoring their learning and professional development (Abadia, 2015). Determining the competences expected by university students from their professors is a generalized concern in training units of University of Lleida, seeking a reference model for the preparation of training plans.

The collection and analysis of students' opinion on teaching quality is, therefore, considered essential. Based on competences previously defined and validated (Torra-Bitlloch et al., 2012), a survey was designed to know their thoughts on the characteristics of a good performing teacher. The purpose of this article is to show results of the opinions and assessments of University of Lleida students on a set of competences that define the teaching function.

\section{Methodology}

\subsection{Participants}

The project involved University of Lleida, Spain. The surveys were distributed among students of undergraduate and postgraduate universities: 1,263 on the former and 170 Master students. All areas of knowledge were sampled: "Social and Legal Sciences" ( $n=270)$, "Engineering and Architecture" ( $n=114)$, "Art and Humanities" $(n=350)$, "Health Sciences" ( $N=295)$ and "Sciences" $(n=234)$ for undergraduate students. Data dates from 2014 to 2015 . 


\subsection{Procedure}

The minimum sample required by university, area of knowledge and -in the case of students- by undergraduate or master course was estimated. For both surveys, the minimum sample was calculated setting a maximum error of $5 \%$, a confidence interval of $95 \%$ and a homogeneity level of $50 \%$. The necessary proportionality was kept according to the populations to which they correspond (random sample stratified with proportional fixation).

\subsection{Material}

The survey validated by the IGTT group (Torra Bitlloch et al., 2012), reviewed and adapted within the REDU2012 project, was used for student data collection on teaching skills.

The survey was implemented with the JotForm tool (http: //www.jotform.com), which allows the creation of online forms optimized for mobile devices. It was designed for students to give their opinion, anonymously, about the characteristics that define a good university teacher. It aimed to be more attractive and manageable for those who wanted to answer via mobile phone, thus facilitating participation. The survey was applied using a system that guarantees privacy through SSL (Secure Sockets Layer) protocols. To avoid multiple responses from the same user, answers were subjected to verification by means of cookies (basic control).

The survey was organized in three sections: a) participant's basic information: area of knowledge, level of studies, course and sex, b) Questions (16 items) related to the different components that define the teaching competences identified in the IGTT project. A rating scale of 1 to 10 was used, where 1 was "not important to be a good teacher", and 10 "very important to be a good teacher". The first three items referred to interpersonal competence; items 4, 5, 6 and 7, to methodological; items 8 and 9, to communicative; items 10, 11, 12 and 13, to teaching planning and management; items 14 and 15 to teamwork; and item 16 to innovation, c) Scale to prioritize four competences according to the importance they were given ( 1 being the most important and 4 the least important).

The link to the survey was sent to all undergraduate/graduate and master's degree students through a dissemination list from the Vice-Rector's Office, complying with the Data Protection Law. It was accompanied by a letter of introduction, briefly explaining the project's objectives, asking for their collaboration, and offering a result consultation. The link was available for 3 weeks and, once 15 days had passed, a reminder notice was sent to encourage participation. Once the answers were received, the data file was refined, considering only fully complete surveys as valid.

\subsection{Data analysis}

Univariate and multivariate descriptive techniques were used to show how the respondents assessed each one of the competences, and their indicators according to sex, branch of knowledge, and course. Variance analysis of the different factors was performed with an ANOVA test.

To analyze if mean differences for each category were significant, the Kruskal-Wallis test was used, since variables studied did not follow the normal distribution.

\section{Results}

Given the particular characteristics of the group of undergraduate students in relation to postgraduate students, and in order to obtain maximum representativeness and reliability, both groups were understood as two separate populations, ergo, two samples have been considered. Results focus mainly on degree students in relation to those getting a master's degree. 
The survey provided to students contained 16 questions regarding the different characteristics that would define a good teacher. Table 2 gathers all scores obtained.

Regarding to gender, $54.8 \%$ of the students who participated in the study were women, and $45.2 \%$ were men, averaging 23.4 years of age (5.9 standard deviation). Answer distribution by areas of knowledge were: $21.3 \%$ Social and Legal Sciences, 9.0\% in Engineering and Architecture, 27,7\% in Art and Humanities, 23.5\% in Health Sciences, and $18.5 \%$ in Sciences.

Course distribution can be considered quite homogeneous from the 1st to 3rd grade courses, though fewer students from this last grade answered: only $8 \%$ of the students enrolled in their last year of studies completed the survey. Regarding the Master students, when there was a large majority in one year, there was no significant difference.

Question assessment has been typically superior in all items by women than men. There were no significant differences between academic courses. As for areas of knowledge, generally "Clearly explaining subject contents is the teacher's duty" arose most unanimity among students of all areas, considering it important.

There were differences between Engineering, Architecture and Science students and those of Arts and Humanities and Social and Legal Sciences on "the importance of teachers listening to students and encouraging dialogue", where the first group deemed it less important than the second.

Regarding the "encourage a trusting and tolerant environment in the classroom" competence, responses can be grouped in two areas of knowledge categories: Engineering and Architecture, and Sciences students valued it the less, while Art and Humanities, Social and Legal Sciences and Health Sciences students think it was important that a teacher foster these characteristics in a classroom.

Health Sciences students, in relation to those in other areas of knowledge, gave a higher value to the fact that teachers use "assessment methods consistent with the course objectives" and to "coordination among subject teachers".

Remaining questions maintained similar results across areas of knowledge, usually grouped in Social and Legal Sciences; Art and Humanities and Health Sciences on the one hand, and Engineering and Architecture and Sciences on the other.

As evidenced in Table 2, best-valued item average by undergraduate students were: "Clearly explains subject contents"," Motivates students in their learning process" and "Use teaching-learning methods coherent with the objectives of the subject". The lowest rated items were "Coordinate with faculty on other courses", "Encourages participation and collaborative work" and "Follows the program/guides the course".

Master students valued the ability of teachers to "stimulate reflection" and "provide feedback" far more than grade-level students. The lowest rated items by graduate students were: "Coordinate with faculty on other courses" and "Encourage participation and collaborative work".

Significant differences were observed between the undergraduate and graduate students in reporting on planning, in specifying evaluation criteria and in following the program. 
Table 2

Score summary from the survey

\begin{tabular}{|l|c|c|}
\hline \multicolumn{1}{|c|}{ Question (Q) } & $\begin{array}{c}\text { Mean Score } \\
\text { (Undergrad) }\end{array}$ & $\begin{array}{c}\text { Mean Score } \\
\text { (Master) }\end{array}$ \\
\hline Clearly explain contents & 9.5 & 9.4 \\
\hline Motivate learning & 9.4 & 9.3 \\
\hline Coherence on t-I methods and objectives & 9.1 & 8.9 \\
\hline Evaluation coherence with objectives & 8.8 & 8.5 \\
\hline Specify evaluation criteria & $8.7^{*}$ & 7.1 \\
\hline Build trust and tolerance & 8.4 & 8.1 \\
\hline Listening to students & 8.3 & 8 \\
\hline Stimulating reflection & 7.9 & $9.2^{*}$ \\
\hline Inform on planning & $8.1^{*}$ & 7.1 \\
\hline Coordination with other teachers in the course & 7.3 & 7.6 \\
\hline Highlighting relevant contents & 7.1 & 7.5 \\
\hline Proposing innovations to improve t-I & 6.9 & 6.6 \\
\hline Provide feedback & 6.8 & $8.1^{*}$ \\
\hline Follow program & $7 *$ & 5 \\
\hline Encourage participation and collaborative work & 5.5 & 5.3 \\
\hline Coordinate with faculty on other courses & 5.4 & 4.9 \\
\hline
\end{tabular}

$* p<0.05$ degree vs. master

In the scale item to prioritize four competences according to their perceived importance (table 3), communicative and interpersonal competence were the most valued ones.

Table 3

Scale to prioritize competences according to importance given by students to the question "What should a good teacher have?", according to categories:

\begin{tabular}{|l|c|c|}
\hline \multicolumn{1}{|c|}{ Competence } & $\begin{array}{c}\text { Percentage } \\
\text { (Undergrad) }\end{array}$ & $\begin{array}{c}\text { Percentage } \\
\text { (Master) }\end{array}$ \\
\hline Communicative & $32 \%$ & $19 \%$ \\
\hline Interpersonal & $21 \%$ & $24 \%$ \\
\hline Methodological & $16 \%$ & $18 \%$ \\
\hline Innovation & $8 \%$ & $10 \%$ \\
\hline Technical-scientific & $7 \%$ & $14 \%$ \\
\hline Teaching planning and management & $9 \%$ & $8 \%$ \\
\hline Teamwork & $7 \%$ & $6 \%$ \\
\hline
\end{tabular}

\section{Discussion}

This research identified the students' perception of importance of lecturers' managerial competencies at the University of Lleida, (Spain).

The highest scores obtained in the study correspond to communicative competences. Studies such as that of Brožová, Horáková \& Fiedler (2018) or Blašková, Blaško \& Kucharčíková, (2014) pointed out the teaching communication skills as essential to improve their learning. 
Considering these competences, Zabalza (2003) states: "tradicionalmente la competencia comunicativa ha sido la competencia docente por antonomasia. Si hubiera que condensar en unas pocas palabras la imagen más común de un buen profesor tendríamos que recoger justamente esa idea, que sabe explicar bien su materia"3.

Another of the improvement skills valued by students has been interpersonal competence. In this line, a high estimation of interpersonal competence emphasizes the importance of developing emotional abilities in students, which contribute to their wellbeing and emotional balance (Gonzalez \& Garcia, 2013). In this change of paradigm, by giving prominence to student learning, new forms of tutoring, claimed by students, appear (Casero, 2010).

Specify evaluation criteria, informing the planning and fulfilling the program/guiding the course is valued much less in postgraduate university education. The works of Brožová, Horáková \& Fiedler (2018) or Blašková, Blaško \& Kucharčíková, (2014) point out that the competencies group Organization of the lecture has the lowest importance for students. By cons in our study, while undergraduate students seemed very focused on their final grades and intent on knowing exactly how the course can be overcome, Master students were interested in achieving an in-depth knowledge of the specialty they have chosen, valuing significantly the stimulation of reflection and getting feedback.

Both undergraduate and Master students deemed insignificant innovative proposals to improve teachinglearning process. Our results differ significantly from those found by Brožová, Horáková \& Fiedler (2018). In your work, the students welcomed the ability of the lecturers to use innovative teaching techniques. These results must be considered in order to undertake quality follow-up actions and the incorporation of improvement actions in this field (Pagès et al., 2016).

Among the teaching skills least valued by students are those of teaching planning and management and teamwork, which is not strange, since the knowledge they have of these is indirect. Also the studies by Brožová, Horáková \& Fiedler (2018) or Blašková, Blaško \& Kucharčíková, (2014) concluded the competencies group Organisation of the lecture has de lowest importance for students. The European university is in a process of change driven by the EHEA, but it is paradoxical that the current idea of University has hardly changed in relation to the traditional concept of it, and that recent movements in educational technology are the drive behind university management model modifications. Changes are needed to achieve a flexible and open university to answer to the challenges that society, cultural, scientific, technical and professional development demand in every historical moment.

\section{Conclusions}

The highest scores obtained in the study correspond to communicative, interpersonal and methodological competences. Students consider teaching planning and management, as well as teamwork as less important.

Regarding methodological competencies, students believed that current university studies should include methodological strategies (learning and evaluation) appropriate to the needs of each area of knowledge.

Students' opinion in this study will be very useful to carry out university teacher training programs. This article provides evidence and considerations on training needs for university professors. The purpose is to look for

\footnotetext{
3 "Traditionally, communicative competence has been the teaching competence par excellence. If the most popular image of a good teacher had to be condensed in a few words it would be exactly in that idea: he/she knows how to explain the content well".
} 
common lines to guide, in an adequate and focused way, university teacher training plans regarding transverse teaching competences.

\section{Funding:}

"Marc de Referència Competencial pel disseny dels Programes de Formació Docent per al Professorat Universitari" Government of Catalonia AGAUR grant “MQD" (2010MQD00049) from 21/03/2010 to 30/10/2012. And "Propuesta de un marco de referencia competencial del profesorado universitario y adecuación de los planes de formación basado en competencias docentes" Red Estatal de Docencia Universitaria grantREDU-2012 from $03 / 07 / 2012$ to $30 / 10 / 01 / 09 / 2014$

\section{Bibliographic references}

Abadía, R.A., García, C.B., Artur, M.I.U., Cebrián, M.D.M., Sabaté, S., Jorba, H., \& Pagès, T. (2015). Competencias del buen docente universitario.: Opinión de los estudiantes. REDU: Revista de Docencia Universitaria, 13(2), 19.

Brožová, H., Horáková, J \& Fiedler, J. (2018). Lecturers' Managerial competencies important for students at the Czech University of Life Sciences. Problems of education in the $21^{\text {st }}$ Century, 76(4), 465.

Blašková, M., Blaško, R., \& Kucharčíková, A. (2014). Competences and competence model of university teachers. Procedia - Social and Behavioral Sciences, 159, 457-467. doi:10.1016/j. sbspro.2014.12.407.

Casero, A.C. (2010). ¿Cómo es el buen profesor universitario según el alumnado?. Revista española de pedagogía, 236, 223-242.

González, M.L.G., \& García, C. L. (2013). Competencias emocionales y rendimiento académico en estudiantes universitarios. Revista Electrónica interuniversitaria de formación del profesorado. 16(2), 13-25. Retrieved from: https://revistas.um.es/reifop/article/view/181031

Mas, O. \& Tejada, J. (2013). Funciones y competencias en la docencia universitaria. Editorail Sintesis. Madrid. ISBN: 978-84-995899-1-6.

Pagès, T., Santigosa, R. S., Campos, J. A.A., Fernández, E.G., Ruiz, L.M., \& Ferré, M.M. (2016). La formación docente del profesorado de la Universidad de Barcelona: satisfacción, transferencia e impacto. @ tic. Revista d'innovació educativa. 17, 41-48.

Rodríguez-Gómez, D., \& Gairín, J. G. (2015). Innovación, aprendizaje organizativo y gestión del conocimiento en las instituciones educativas. Educación, 24(46), 73-90.

Tejada, J. (2009). Competencias docentes. Profesorado. Revista de currículum y formación del profesorado. 13 (2), 1-15.

Torra Bitlloch, I.; Corral, I.D.; Pérez, M.J.; Valderrama, E.; Màrquez, M.D.; Sabaté, S.; ... \& Estebanell, M. (2012). Identificación de competencias docentes que orienten el desarrollo de planes de formación dirigidos a profesorado universitario. REDU, Revista de Docencia Universitaria. 10(2), 21-56. Restrieved from: https://polipapers.upv.es/index.php/REDU/article/view/6096

Triadó, X.M.; Estebanell, M.; Márquez Cebrián, M.D. \& Del Corral Manuel de Villena, I. (2014). Identificación del perfil docente en educación superior. Evidencias para la elaboración de programas de formación continua del profesorado universitario. Revista Española de Pedagogía, 257, 55-76. Restrieved from: https://revistadepedagogia.org/Ixxii/no-257/identificacion-del-perfil-competencial-docente-en-educacion- 
superior-evidencias-para-la-elaboracion-de-programas-de-formacion-continua-del-profesoradouniversitario/101400010384/

Valcárcel, M. (2005). La preparación del profesorado universitario para la convergencia europea en educación superior. Educatio, 23, 209-213. Restrieved from: https://revistas.um.es/educatio/article/view/130

Zabalza, M. Á. (2003). Competencias docentes del profesorado universitario: calidad y desarrollo profesional. Narcea ediciones.

Esta obra está bajo una Licencia Creative Commons

Attribución-NoCommercial 4.0 International

\section{(cc) BY-NG}

